STATE OF ILLINOIS

DEPARTMENT OF REGISTRATION AND EDUCATION

The Late Woodfordian Jules Soil and Associated Molluscan Faunas John C. Frye A. Byron Leonard H. B. Willman H. D. Glass Leon R. Follmer

ILLINOIS STATE GEOLOGICAL SURVEY John C. Frye, Chief Urbana, IL 61801 
Digitized by the Internet Archive in 2012 with funding from University of Illinois Urbana-Champaign 


\title{
THE LATE WOODFORDIAN JULES SOIL AND ASSOCIATED MOLLUSCAN FAUNAS
}

\author{
John C. Frye, A. Byron Leonard, H. B. Willman, \\ H. D. Glass, and Leon R. Follmer
}

\begin{abstract}
The Jules Soil formed during the late Woodfordian episode of maximum glacial retreat in the Lake Michigan Glacial Lobe during the interval between 15,500 and 16,500 radiocarbon years $B . P$. The soil is directly radiocarbon dated and stratigraphically framed by a group of dates. The molluscan faunas above and below the soil indicate a cool, moist climate. The significantly higher content of expandable clay minerals (montmorillonite) in the Jules Soil than in the loess above and below indicates that there was a decrease in Lake Michigan outwash discharged to the Illinois Valley during the episode of soil formation.
\end{abstract}

\section{GENERAL STATEMENT}

The Jules Soil was named in 1970 (Willman and Frye, 1970) from its occurrence in the Peoria Loess at the Jules Section (Frye, Glass, and Willman, 1968), Cass County, Illinois. The soil had earlier been recognized as an unnamed soil in the Peoria Loess in the Frederick South Section (Leonard and Frye, 1960), and in other loess sections in the lower Illinois Valley and the East St. Louis area (Frye, Glass, and Willman, 1962; Frye and Willman, 1963). The stratigraphic significance of this weakly developed soil was discussed by Frye and Willman (1973), who suggested an age of slightly more than 17,000 radiocarbon years B.P. The presence of this minor soil in the Peoria Loess is evidence of a pause in loess deposition that reflects a significant glacial retreat during late Woodfordian time in the region of the type Wisconsinan.

In the steepest valley bluffs at the margin of the lower Illinois Valley and in the Mississippi Valley bluffs in Madison and St. Clair Counties, the Jules Soil is split into a complex of two or more A-horizons separated by a foot or more of typical loess. However, where the exposures are extensive enough to trace the soil as much as 100 yards away from the bluff line, the multiple 
A-horizons merge into a single A-horizon only 1 to 2 feet thick, the thickness of loess above the soil thins sharply, and the texture of the loess becomes finer grained. The type section of the Jules Soil is in such a situation.

Exposures in roadcuts at the Cottonwood School South Section, 1 mile west of the Jules Section in Cass County, Illinois, afforded an especially good opportunity to study this buried soil, including its age by radiocarbon dating; the molluscan faunas above and below the soil; and the clay mineral composition of the deposits. The Cottonwood School Section had been studied in some detail (Willman and Frye, 1970); the Cottonwood School South Section occurs in a roadcut immediately south of this classic section. A description of the Cottonwood School South Section follows.

\title{
Cottonwood School South Section
}

Cottonwood School South Section, measured in roadcuts in NW/ $\mathrm{NW}^{\frac{1}{4}} \mathrm{SW} \frac{1}{4}$ sec. 12, T. 18 N., R. 11 W., Cass County, Illinois (1972). (Sample numbers preceded by "P" are the numbers used in the Illinois State Geological Survey collection of lithologic samples.)

Thickness (feet)

\author{
Pleistocene Series \\ Wisconsinan Stage \\ Woodfordian Substage \\ Peoria Loess
}

6. Loess, coarse; contains Modern Soil in top; calcareous in lower part; the gray to gray-tan A-horizon of the surface solum is granular and friable; the light tan-brown Bhorizon has weak textural contrast and indistinct structure . 6.0

5. Loess, coarse, calcareous, massive, fossiliferous, gray to gray-tan; radiocarbon date on snail shells $10,410 \pm 650$ (ISGS-138). Samples: P-7586, $\frac{1}{2}$ foot below top; P-7585, middle; P-7584, $\frac{1}{2}$ foot above base . . . . . . . . .

4. Loess, massive, calcareous, gray, highly fossiliferous; radiocarbon date on snail she11s $15,640 \pm 580$ (ISGS-137). Samples: P-7583, top; P-7582, $\frac{1}{2}$ foot above base; P-7581, base ................... 1.0

3. Jules Soil (A-horizon), silt with some clay; dark graybrown in upper part becoming lighter tan-brown in lower part; granular to massive, weakly calcareous, less friable than bed above; generally lacks snail shells but contains rare examples of Succinea sp. and some small nodules of $\mathrm{CaCO}_{3}$. Radiocarbon date on humus $12,740 \pm 210$ (ISGS-195); date on humus from Jules Soil at the type section, 1 mile to the east of this section, $15,020 \pm 300$ (ISGS-179). Samples: P-7580, top; P-7579, $\frac{1}{2}$ foot below top; P-7578,

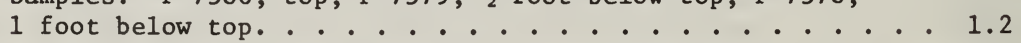

2. Loess (C-horizon of Jules Soil), medium, massive, calcareous, fossiliferous, gray to tan-gray; contains nodules of $\mathrm{CaCO}_{3}$ up to $\frac{1}{2}$ inch in diameter. Radiocarbon date on outer one-third of nodules, 5,030 \pm 100 (ISGS-139A); on middle one-third of nodules, $5,867 \pm 80$ (ISGS-139B); on inner onethird of nodules, 7,370 \pm 140 (ISGS-139C). Samples: P-7577, top $\frac{1}{4}$ foot; P-7576, 旁 foot below top............... 0.8

1. Loess, medium, massive, calcareous, friable; contains sparsely distributed snail shells; gray, with some streaks of light brown; slumped in lower part. Samples: P-7575,

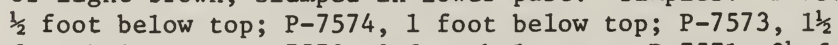

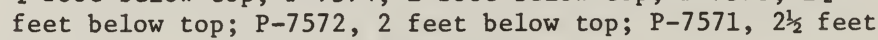
below top. To level of road grade. . . . . . . . . 6.0 
The Peoria Loess includes all of the eolian silts and fine sands above the Robein Silt of Farmdalian age and beyond the limit of Woodfordian glacial tills. It is typically developed south of Peoria along the Illinois Valley and in the Mississippi Valley south of the southern terminus of the Illinois River. The Peoria Loess in the Frederick South Section and the Cottonwood School Section were suggested as reference sections for the type Woodfordian (Frye, Willman, Rubin, and Black, 1968).

More than 30 radiocarbon dates determined in central and northern Illinois place the Robein Silt, of Farmdalian age, within the time span of 28,000 to 22,000 radiocarbon years B.P. (Willman and Frye, 1970). Several additional dates from the Morton Loess (stratigraphically equivalent to the lowermost part of the Peoria Loess) and from the basal part of the Wedron Formation tills fall within the range of 19,000 to 22,000 radiocarbon years B.P. Within the Peoria Loess are two radiocarbon dates, $17,950 \pm 550$ (W-1055) from the Collinsville Section and 17,100 \pm 300 (W-730) from the Burdick Branch Section (Frye, Glass, and Willman, 1962), that were determined on materials that are stratigraphically below the position of the Jules Soil.

Radiocarbon dates determined from the Cottonwood School South and Jules Sections are placed stratigraphically in the described section in this report. The date of $10,410 \pm 650$ (ISGS-138), determined on snail shells from $11 / 2$ to $21 / 2$ feet above the top of the Jules Soil, is the youngest date so far determined from the Peoria Loess in Illinois. The youngest date previously determined is $13,700 \pm 230$ ( I-1720) on snail shells from the uppermost part of the Peoria at the Bald Bluff Section (Frye, Glass, and Willman, 1968) in the bluffs of the Mississippi Valley in Henderson County. Immediately below the youngest date at Cottonwood School South, however, a date of $15,640 \pm 580$ (ISGS-137) was determined on snail shells from the one-foot interval immediately above the top of the Jules Soil. In an effort to date the soil directly, dates were run on organic carbon extracted from the sediments. At Cottonwood School South the organic carbon content of the one foot of Jules Soil from which humus was extracted ranges from 0.20 percent to 0.37 percent. The dates from organic carbon from the Jules Soil were 15,020 \pm 300 (ISGS-179) at the Jules Section, and 12,740 \pm 210 (ISGS-195) at the Cottonwood School South Section. As the probability of some contamination by modern hair-roots in such shallowly buried soils is high, these soil dates are probably somewhat too young. A reasonable evaluation of the available dates indicates that the Jules Soil developed during part of the interval between 15,500 and 16,500 B.P. rather than at about 16,500 B.P. (Frye, Glass, and Willman, 1968) or 17,000 B.P. (Frye and Willman, 1973) as has been suggested.

In an attempt to relate the nodules of $\mathrm{CaCO}_{3}$ that occur in the one-foot zone below the base of the soil to the soil-forming process, they were radiocarbon dated. One-third, by weight, of a group of nodules was dissolved and dated as 5,030 \pm 100 (ISGS-139A), another one-third was dissolved and dated as $5,867 \pm 80$ (ISGS-139B), and the remaining one-third was dissolved and dated as $7,370 \pm 140$ (ISGS-139C). From the dates obtained, it is concluded that most of the concretionary growth of the nodules took place after the development of the Jules Soil and, as some concretions occur within the Jules Soil itself, they may be largely related to the development of the modern surface solum.

The Jules Soil is an immature A-C profile. Carbonate minerals persist through the solum; but with the exception of a rare Succinea, snail shells are not present in bed 3 , the A-horizon of the soil. The A-horizon is darker colored and less friable than the loess above and below; it is more clayey and is streaked with some secondary carbonate, but it lacks distinctive soil structure. The 
C-horizon contains abundant nodules of $\mathrm{CaCO}_{3}$ and fossil snail shells; it is massive and lighter colored than the A-horizon. A B-horizon is not recognizable in the profile. The percent of less-than-2-micron clay through the profile, shown in figure 1 and listed in table 1 , shows a progressive upward trend of

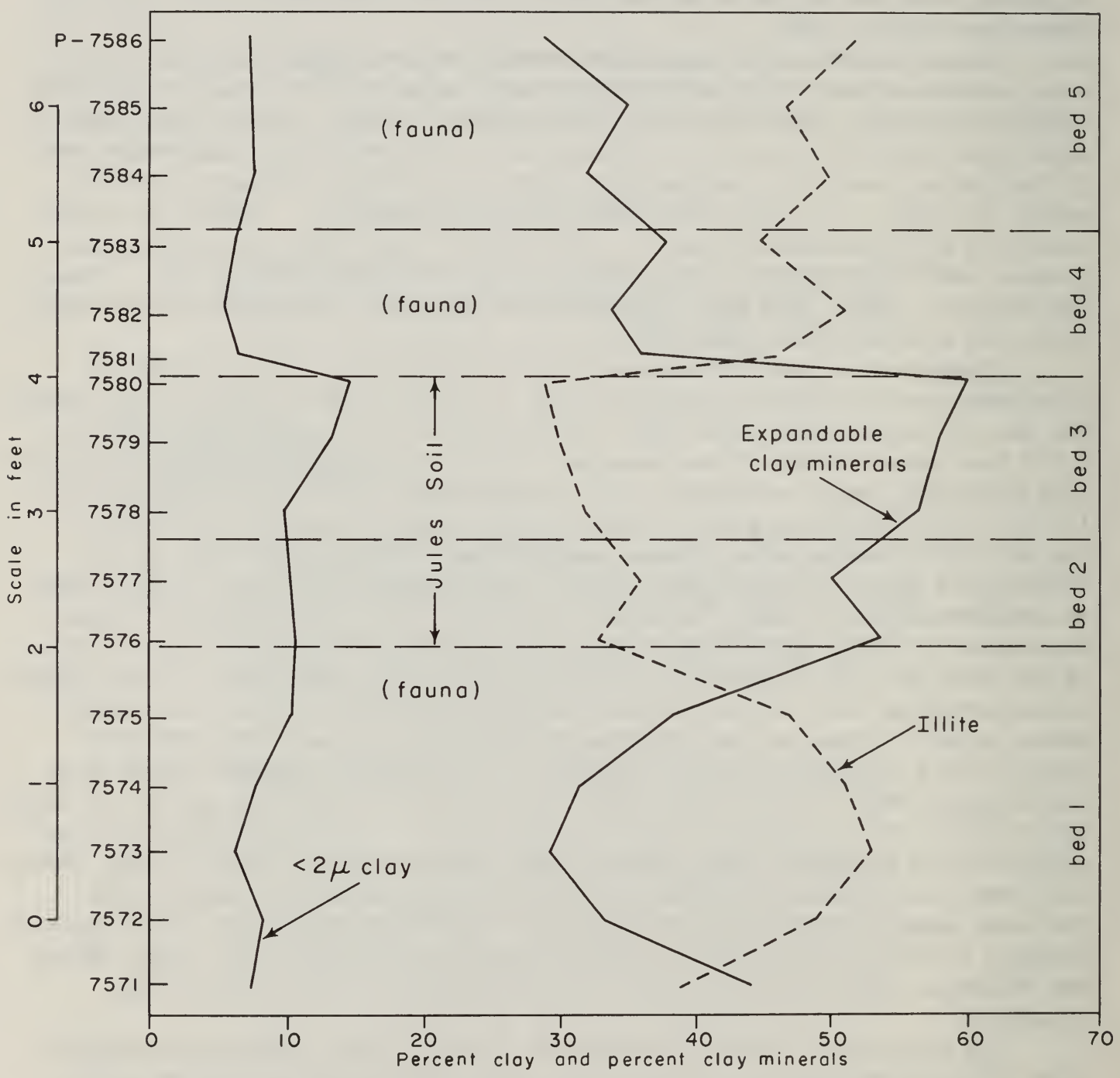

Fig. 1 - Cottonwood School South Section, NW $\frac{1}{4}$ NW $\frac{1}{4}$ SW $\frac{1}{4}$ sec. 12, T. 18 N., R. $11 \mathrm{~W}$., Cass County, showing percent of less-than-2-micron clay in Peoria Loess and percent of illite and expandable clay minerals in the clay mineral assemblage. Sample numbers at left are ISGS file numbers, and bed numbers at right refer to numbered beds in the described section in this report. 
TABLE 1 - GRAIN SIZE AND CLAY-MINERAL COMPOSITION OF PEORIA LOESS AT COTTONWOOD SCHOOL SOUTH SECTION

\begin{tabular}{|c|c|c|c|c|c|c|c|}
\hline \multirow[b]{2}{*}{$\begin{array}{c}\text { Sample } \\
\text { no. }\end{array}$} & \multirow[b]{2}{*}{$\begin{array}{l}\text { Grave1* } \\
(\%)\end{array}$} & \multicolumn{3}{|c|}{$\begin{array}{c}\text { Matrix } \\
\text { particle size } \\
(\%)\end{array}$} & \multicolumn{3}{|c|}{$\begin{array}{c}\text { Clay minerals } \\
(\%)\end{array}$} \\
\hline & & Sand* & Silt & Clay & $\begin{array}{l}\text { Expandable } \\
\text { clay minerals }\end{array}$ & Illite & $\begin{array}{l}\text { Kaolinite } \\
\text { and chlorite }\end{array}$ \\
\hline$P-7586$ & 2.2 & 1.7 & 90.8 & 7.5 & 29 & 52 & 19 \\
\hline P-7585 & 3.3 & 0.6 & 92.0 & 7.4 & 35 & 47 & 18 \\
\hline P-7584 & 0.7 & 1.2 & 91.1 & 7.7 & 32 & 50 & 18 \\
\hline P-7583 & 0.8 & 0.4 & 93.4 & 6.2 & 38 & 45 & 17 \\
\hline$P-7582$ & 0.0 & 0.8 & 93.5 & 5.7 & 34 & 51 & 15 \\
\hline$P-7581$ & 0.4 & 1.3 & 92.2 & 6.5 & 36 & 46 & 18 \\
\hline P-7580 & 3.1 & 2.0 & 83.2 & 14.8 & 60 & 29 & 11 \\
\hline$P-7579$ & 1.1 & 1.5 & 85.3 & 13.2 & 58 & 30 & 12 \\
\hline$P-7578$ & 0.4 & 0.9 & 89.2 & 9.9 & 56 & 32 & 12 \\
\hline P-7577 & 3.6 & 1.0 & 88.8 & 10.2 & 50 & 36 & 14 \\
\hline$P-7576$ & 1.5 & 1.7 & 87.6 & 10.7 & 53 & 33 & 14 \\
\hline$P-7575$ & 0.9 & 1.0 & 88.7 & 10.3 & 38 & 47 & 15 \\
\hline$P-7574$ & 0.5 & 0.8 & 91.2 & 8.0 & 31 & 51 & 18 \\
\hline$P-7573$ & 0.6 & 0.3 & 93.4 & 6.3 & 29 & 53 & 18 \\
\hline$P-7572$ & 0.6 & 1.1 & 90.7 & 8.2 & 33 & 49 & 18 \\
\hline$P-7571$ & 0.8 & 1.3 & 91.4 & 7.3 & 44 & 39 & 17 \\
\hline
\end{tabular}

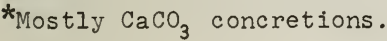

increase in percentage of clay that is sharply terminated at the top of the Jules Soil. The clay mineral composition (fig. l and table l) shows a sharp change at both the top and bottom of the soil. Clay mineral data for the nearby Jules Section have been published previously (Frye, Glass, and Willman, 1968) and show similar relationships.

In order to show the extreme situation that locally occurs at the bluff line in exceptionally thick, coarse-textured Peoria Loess, we sampled the Jules Soil interval at the Bunkum South Section, SE $\frac{1}{4} N W \frac{1}{4} N E \frac{1}{4} \operatorname{Sec} .24$, T. 2 N., R. 9 W., St. Clair County. The clay mineral data and the positions of A-horizons are shown in figure 2. At this locality four A-horizons occur within a vertical distance of 9 feet and are separated by 1 to $21 / 2$ feet of loess that superficially resembles the deposit above and below the soil zone. Although the sequence is much thicker and the deposits are coarser textured, the relationship of the clay mineral assemblages strikingly parallels that shown at the Cottonwood School South Section (figs. 1 and 2). 


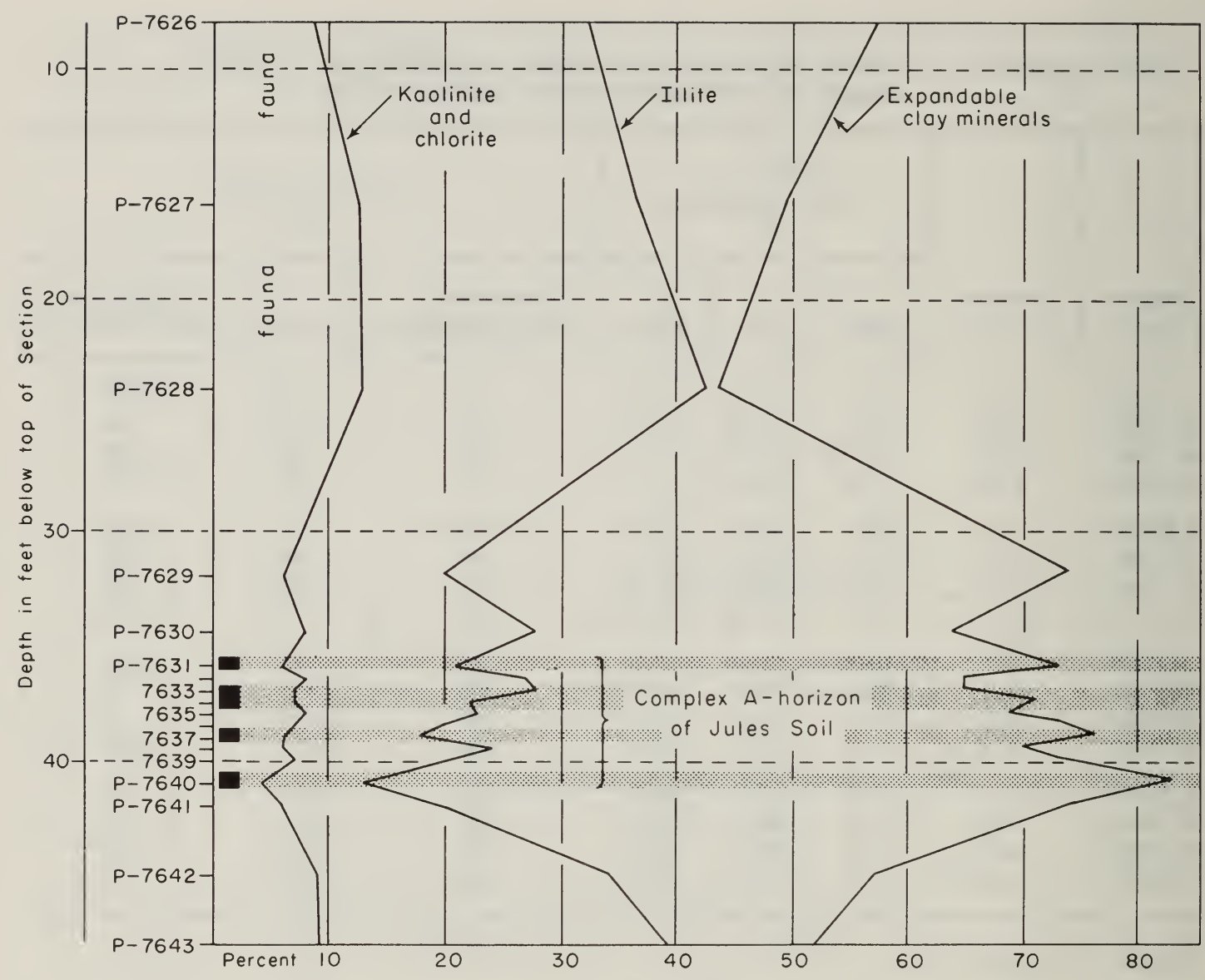

Fig. 2 - Bunkum South Section, measured in cuts of Interstate Highway 64 in SE $\frac{1}{4}$ NW $\frac{1}{4}$ NE $\frac{1}{4}$ sec. 24, T. 2 N., R. 9 W. , St. Clair County, showing percent of illite, expandable clay minerals, and kaolinite plus chlorite in the clay mineral assemblage in the Peoria Loess. The complex A-horizon of the Jules Soil is shown in relation to clay mineral percentages. Sample numbers at left are ISGS file numbers.

\section{PALEONTOLOGY}

Molluscan faunas occur in beds 5 and 4 above the Jules Soil and in 1-2 below the Jules Soil in Peoria Loess at the Cottonwood School South Section; in two faunal zones above the Jules Soil at the Bunkum South Section in St. Clair County near the village of Bunkum; and above the position of the Jules Soil in Peoria Loess in the Bald Bluff Section in Henderson County, where radiocarbon dating demonstrates the age of the fauna to be equivalent to that of faunas above the Jules Soil at the Cottonwood School South locality (fig. 3). While shells are sufficiently abundant in the deposits in the Bunkum South Section to permit dating them by the radiocarbon method, this has not yet been done. The two uppermost molluscan faunas at the Cottonwood School South Section have been 


\begin{tabular}{|c|c|c|c|c|c|c|}
\hline \multirow[b]{2}{*}{ MOLLUSCAN SPECIES } & \multicolumn{3}{|c|}{ Cottonwood School South } & \multirow{2}{*}{ 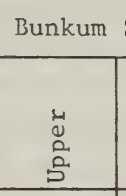 } & \multirow{2}{*}{\begin{tabular}{|} 
South \\
\\
0 \\
0 \\
3 \\
0
\end{tabular}} & \multirow{2}{*}{$\begin{array}{l}\text { Bald } \\
\text { Bluff }\end{array}$} \\
\hline & $\ddot{\Xi}$ in & $\underset{\Xi}{\oplus}+$ & 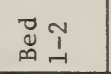 & & & \\
\hline \multicolumn{7}{|l|}{ Anguispira altermata (Say) } \\
\hline \multicolumn{7}{|l|}{ Columella alticola (Ingersoll) } \\
\hline \multicolumn{7}{|l|}{ Deroceras Zaeve (Müller) } \\
\hline \multicolumn{7}{|l|}{ Discus cronkhitei (Newcomb) } \\
\hline \multicolumn{7}{|l|}{ Discus macclintocki (F. C. Baker) } \\
\hline \multicolumn{7}{|l|}{ Euconulus fulvus (Mü1ler) } \\
\hline \multicolumn{7}{|l|}{ Gastrocopta armifera (Say) } \\
\hline \multicolumn{7}{|l|}{ Hendersonia occulta (Say) } \\
\hline \multicolumn{7}{|c|}{ Lymnaea (Fossamia) dalli (F. C. Baker) } \\
\hline \multicolumn{7}{|l|}{ Lymnaea (Fossaria) parva Lea } \\
\hline \multicolumn{7}{|l|}{ Mesodon thyroidus (Say) } \\
\hline \multicolumn{7}{|l|}{ Pupizla muscomom (Linné) } \\
\hline \multicolumn{7}{|l|}{ Pupoides albilabris (Say) } \\
\hline \multicolumn{7}{|c|}{ Retinella (Nesovitrea) electrina (Gould) } \\
\hline \multicolumn{7}{|l|}{ Stenotrema Zeaii (Binney) } \\
\hline \multicolumn{7}{|l|}{ Succinea gelida F. C. Baker } \\
\hline \multicolumn{7}{|l|}{ Succinea pleistocenica F. C. Baker } \\
\hline \multicolumn{7}{|l|}{ Succinea (Catinella) sp. } \\
\hline \multicolumn{7}{|l|}{ Triodopsis multilineata (Say) } \\
\hline \multicolumn{7}{|l|}{ Vallonia gracilicosta Reinhardt } \\
\hline \multicolumn{7}{|l|}{ Vertigo alpestmis oughtoni Pilsbry } \\
\hline \multicolumn{7}{|l|}{ Vertigo hannai Pilsbry } \\
\hline Total number of species & 12 & 12 & 14 & 4 & 9 & 11 \\
\hline
\end{tabular}

Fig. 3 - Composition of molluscan faunas of the upper part of the Peoria Loess in central and western Illinois. The stratigraphic position and relation to radiocarbon dates of the three faunas from the Cottonwood School South Section (NW $\frac{1}{4} \mathrm{NW} \frac{1}{4}$ SW $\frac{1}{4} \mathrm{sec} .12, \mathrm{~T} .18$ N., R. 11 W., Cass County) are given in the described stratigraphic section. The relation of the two faunas from the Bunkum South Section (SE $\frac{1}{4} N W \frac{1}{4}$ NE $\frac{1}{4}$ Sec. 24 , T. 2 N., R. 9 W. , St. Clair County) to the Jules Soil is shown in figure 2. The position of the fauna at the Bald Bluff Section (NE $\frac{1}{4} \mathrm{NE} \frac{1}{4} \mathrm{SE} \frac{1}{4} \mathrm{Sec}$. 20 , T. 12 N., R. 4 W. , Henderson County), the associated clay minerals, and the position of the radiocarbon date have been described by Frye, Glass, and Willman (1968). 
directly dated, and the fauna occurring below the Jules Soil is stratigraphically framed by the date of the Jules Soil (about 16,000 B.P.) and the older dates (about 17,000 B.P.) obtained at the Burdick Branch and Collinsville Sections, previously referred to.

The molluscan faunas compiled on figure 3 comprise 17 genera and a total of 22 species. All are typical terrestrial gastropods, except Lymnaea daZZi and $L$. parva, which belong to a family of aquatic pulmonates; however, these two species tend to live out of the water on mud flats and dead vegetation, at the water's edge, in contrast to the other members of the family Lymnaeidae, which are typically aquatic in habit. Succinea (Catinella) sp., a member of a family of terrestrial habitat preference, also prefers to live among or on vegetation in very wet situations. Deroceras Zaeve, a small slug, likewise prefers wet environments, although it can tolerate habitats far from open water as long as it can find some moisture. Basically, D. Zaeve is a species inhabiting wet woodlands and low terraces along streams.

At least seven of the species collected are no longer found living, at least in Illinois: these include Columelza alticola, now restricted to montane habitats above 7,000 feet in altitude; Hendersonia occulta, once widespread in Illinois, but now restricted to relatively few localities along brushy creeks; Pupilza muscorum, like C. alticola, now restricted to higher elevations and/or latitudes and cooler climates; Succinea gelida, known only as a fossil; Succinea pleistocenica, known only from late Wisconsinan loess; Vertigo alpestris oughtoni, once common in Illinois, but now restricted to high latitudes; and Vertigo hannai, known only as a Pleistocene fossil. The remaining species still live in Illinois; in fact, the majority may be found in appropriate habitats within the areas of this report. Anguispira alternata, Retinella electrina, Stenotrema leaii, and Triodopsis multilineata are essentially woodland species; the others frequent woodland borders or even prairie habitats.

Cottonwood School South Faunal Assemblages. Although differences do exist among the three faunal assemblages known from the loess at this locality, they seem to reflect no more than minor fluctuations in the local environment and/or limitations in the methods of collection. None of the variations among the three faunal assemblages seems clearly related to their respective stratigraphic position or relative age. Six of the species occur in all three of the faunal assemblages, while five species occur in two faunal assemblages. Three species occur in only one.

It seems reasonable to interpret the local habitat as a well-watered upland savanna, varying between woodland and prairie with the passage of time and fluctuations in climatic conditions. Indications are that the climate through the interval 17,000-13,000 B.P. was generally cooler than the present one. A fauna at approximately the same stratigraphic position and of equivalent age, that indicates a comparable habitat, has been described (Leonard and Frye, 1960, locality no. 23) from Richland Loess above Tiskilwa Till along the east side of the Illinois Valley in Tazewell County.

Bunkum South Faunal Assemblages. The uppermost $21 / 2$ feet of Peoria Loess is leached and is in the modern solum. From the base of the solum downward to 8 feet below the top, only a few fossil shells occur; and the upper fauna described here was collected from a zone 8 to 12 feet below the top. The lower fauna was collected from a somewhat more fossiliferous zone 14 to 22 feet below the top. The upper sample yielded four molluscan species from a relatively 
small field sample. Each of these species was also encountered in the lower sample, taken from the loess above the Jules Soil complex (fig. 2). The ecological requirements of the total faunal assemblage suggest a moist, wooded slope. In contrast to the settings at Cottonwood South, Bald Bluff, and the previously mentioned locality in Tazewell County where intermittent ponding is suggested, the molluscan fauna at Bunkum South does not include Lymnaea parva and $L$. dazzi. This fact, coupled with the topographic position on the bluff line and the coarse texture of the loess, suggests that even intermittent ponding did not occur at this locality. There seems to be no stratigraphic significance to the differences between the upper and the lower faunal assemblage; rather, a comparison of the two suggests that the more delicate shells may have been removed from the upper horizon by downward movement of carbonates .

Bald Bluff Faunal Assemblage. The faunal assemblage at this locality is similar to those at the other three localities, although removed from them by a considerable distance. The habitat seems to have been a poorly drained upland prairie to woodland border environment, as attested to by the composition of the fauna, but under a climatic regimen approximately equivalent to that prevailing at the same time at the other localities.

\section{DISCUSSION AND CONCLUSIONS}

The Jules Soil is of stratigraphic significance because its development coincides with the maximum glacial retreat of the Lake Michigan Lobe during the Woodfordian Substage (Frye and Willman, 1973) and may coincide with the interval designated as the Erie Interstade (Dreimanis and Goldthwait, 1973; Morner and Dreimanis, 1973). In the Peoria Loess of the middle Illinois Valley, the soil has been stratigraphically placed between clay mineral Zones II and III previously described by Frye, Glass, and Willman (1968). Its clay mineral assemblage sharply contrasts with that of the loess above and below it because the soil has a much higher percentage of expandable clay minerals. In fact, the clay mineral composition of the Jules Soil resembles that of clay mineral Zones I and IV (derived from a Mississippi Valley source having a relatively high percentage of montmorillonite) more closely than it does Zones II and III, which reflect a source higher in illite in the Lake Michigan Lobe outwash of the Illinois Valley.

The morphology of the Jules Soil at the Jules and Cottonwood School South Sections indicates that it did not form by in situ development downward from a stable land surface, but rather that it is an A-horizon that continued to develop as it was slowly extended upward by continuing but small additions of eolian sediment on the soil surface. This history is indicated by the thickness and character of the A-horizon, which retains primary carbonates throughout, although it is generally lacking in aragonite snail shells; by the lack of a textural, or even a cambic, B-horizon below an A-horizon 1 foot or more thick; and by the lack of discernible weathering effect on the expandable clay minerals. The fact that the percentage of less-than-2-micron clay in the soil is much higher than in the loess above and below it suggests that at least part of the eolian sediment was derived from a more remote source than the nearby Illinois Valley, which was the source for the bulk of the Peoria Loess along the valley bluffs. Also, the progressive upward increase in percentage of clay and of expandable clay minerals suggests that the nearby Illinois Valley loess source was contributing only a small percent of the deposited sediment by the end of Jules Soil development, 
while the sharp decrease in total clay and in percent of expandable clay minerals at the top of the soil indicates a sudden influx of outwash into the Illinois Valley (figs. 1 and 2).

The maximum thickness of the Jules Soil zone as shown by the Bunkum South Section (fig. 2) in the bluff of the Mississippi River Valley, below the mouths of both the Illinois River and the Missouri River, confirms these general conclusions. In addition, the relations in the thickest sequence at the bluff line indicate that the very slow loess deposition during the episode of Jules Soil development was interrupted by minor pulses of more rapid deposition. At the position of the Bunkum South Section, the sediment source for loess has its maximum complexity, as sediment from the Lake Michigan Lobe was contributed by way of the Illinois Valley, from the north by way of the upper Mississippi Valley, and from the west and northwest by way of the Missouri Valley. The complex interrelations of these three contrasting source regions are shown by the clay mineral assemblages (fig. 2), since the Illinois Valley source is characterized by a high percentage of illite, the upper Mississippi source by a moderately high percentage of expandable clay minerals, and the Missouri Valley source by an exceptionally high percentage of expandable clay minerals. As at the Jules and Cottonwood School South Sections, the episode of Jules Soil development is characterized by a marked decrease in sediment from the Lake Michigan Lobe by way of the Illinois Valley.

These data on the Jules Soil are all consistent with the previous interpretation (Frye, Glass, and Willman, 1968; Frye and Willman, 1973) that the soil marks the stratigraphic position of the most extensive glacial withdrawal of the Lake Michigan Lobe during Woodfordian time. The glacier front retreated into the basin of Lake Michigan and much of the outwash that was discharged from the glacier was trapped in the slack waters of the pro-glacial lake. Thus, a significant part of the eolian sediment that was deposited at the Cottonwood School South locality and other localities of the middle Illinois Valley was derived from the high-montmorillonite source of the Mississippi Valley and possibly from other sources farther west. These more remote sources furnished finer textured materials, and the clay fraction contained a much higher percentage of expandable clay minerals, which is characteristic of the northwestern source region. The very slow rate of deposition of eolian sediment allowed A-horizon development to keep pace with the slow rate of deposition, and therefore the Jules Soil is recognizable.

Of all the data presented here in regard to the Jules Soil, the only item that is not compatible with the bulk of the data is the date of $10,410 \pm 650$ (ISGS138) determined on shells only 1 to 2 feet above the date of $15,640 \pm 580$ (ISGS137) determined on shells within 1 foot above the top of the soil. As there is no evidence of soil formation between the dates, as the texture and the clay mineral assemblage of the two zones is similar, as the molluscan faunas of the two zones do not indicate a marked stratigraphic separation, and as there was no glacial outwash being discharged down the Illinois Valley at that time, it seems reasonable to conclude that the uppermost date is too young. If this conclusion is conceded, then the uppermost part of the Peoria Loess at the Cottonwood School South and Jules Sections is latest Woodfordian in age and approximately equivalent in age to the uppermost Peoria Loess of the Mississippi Valley (Bald Bluff Section), which contains the youngest dated fauna at 13,700 \pm 230 (I-1720). 
THE JULES SOIL AND ASSOCIAED MOLLUSCAN FAUNAS II

\section{REFERENCES}

Dreimanis, A., and R. P. Goldthwait, 1973, Wisconsin glaciation in the Huron, Erie, and Ontario Lobes, in Black, R. F., R. P. Goldthwait, and H. B. Willman, eds., The Wisconsinan Stage: Geol. Soc. America Memoir 136, p. 71-106.

Frye, J. C., H. D. Glass, and H. B. Willman, 1962, Stratigraphy and mineralogy of the Wisconsinan loesses of Illinois: Illinois Geol. Survey Circ. $334,55 \mathrm{p}$.

Frye, J. C., H. D. Glass, and H. B. Willman, 1968, Mineral zonation of Woodfordian loesses of Illinois: Illinois Geol. Survey Circ. 427, $44 \mathrm{p}$.

Frye, J. C., and H. B. Willman, 1963, Loess stratigraphy, Wisconsinan classification and accretion-gleys in central-western Illinois: Midwestern Section, Friends of the Pleistocene 14th Ann. Meeting, Illinois Geol. Survey Guidebook Ser. 5, 37 p.

Frye, J. C., and H. B. Willman, 1973, Wisconsinan climatic history interpreted from Lake Michigan Lobe deposits and soils, in Black, R. F., R. P. Goldthwait, and H. B. Willman, eds., The Wisconsinan Stage: Geol. Soc. America Memoir 136, p. 135-152.

Frye, J. C., H. B. Willman, Meyer Rubin, and R. F. Black, 1968, Definition of Wisconsinan Stage: U. S. Geol. Survey Bull. 1274-E, p. El-E22.

Leonard, A. B., and J. C. Frye, 1960, Wisconsinan molluscan faunas of the Illinois Valley region: Illinois Geol. Survey Circ. 304, 32 p.

Morner, Nils-Axel, and A. Dreimanis, 1973, The Erie Interstade, in Black, R. F., R. P. Goldthwait, and H. B. Willman, eds., The Wisconsinan Stage: Geol. Soc. America Memoir 136, p. 107-134.

Willman, H. B., and J. C. Frye, 1970, Pleistocene stratigraphy of Illinois: Illinois Geol. Survey Bull. 94, 204 p. 
Illinois State Geological Survey Circular 486

11 p., 3 figs., 1 table, 2800 cop., 1974

Urbana, IL 61801

Printed by Authority of State of Illinois, Ch. 127, IRS, Par. 58.25. 

CIRCULAR 486

ILLINOIS STATE GEOLOGICAL SURVEY URBANA， IL 61801 